\title{
Editorial
}

\section{Taxation with character}

\author{
Paul R. McDaniel, Hill \& Barlow, Boston
}

Readers of this journal may not realize how difficult is the life of an Intertax editorial writer. Editorials are used by daily newspapers to bring to the attention of readers wrongs that need to be righted, major events that need to be analyzed and actions for the public good that deserve to be praised. As you can appreciate, in the arcane world of international taxation, there are very few topics that can measure up to these criteria. Nonetheless, for the past several years, one or more of us editorialists has been rescued each year by the enactment of foreign tax measures by the US Congress.

The year 1989 was no exception and, in the February issue, Helmut Becker addressed the so-called 'earnings-stripping' provision in the Revenue Reconciliation Act of 1989. In his comments, he raised the interesting point that a characterization rule such as the earnings stripping provision (i.e. from debt to part debt/part equity and from interest to dividend) violated treaty arms length pricing provisions similar to those in Article 9 of the OECD model. I do not happen to share that view since recharacterization of an item often follows a reallocation of an income or deduction item under the arm's length standard. Thus, for example, if one US subsidiary of a foreign parent sells to another subsidiary at a price which is below market, income will be reallocated to the selling subsidiary. However, the cash from resale is in the hands of the purchasing subsidiary. That fact is accounted for by treating the difference between the actual and market price as a dividend to the foreign parent followed by a capital contribution to the purchasing subsidiary. Presumably, the US could apply its normal tax rules to that recharacterized transaction. My own view is that a provision such as Article 9 would not preclude such an action. Similarly, it seems open to Congress to establish uniformly applicable mechanical rules for distinguishing debt from equity without violating arm's length pricing provisions. The treaty problem created by the earnings-stripping provisions is that it is not a rule of general application but is instead directed at selected transactions, principally those involving foreigners.

But Helmut Becker's point that classification provisions can raise treaty override issues is a timely one. Representatives Rostenkowski and Gephardt in mid-March introduced the 'Foreign Tax Equity Act of 1990' (presumably the title is not intentionally humorous!). Among other provisions, it includes a modified version of the rejected 1989 proposal to impose a tax on gains realized by ten per cent or more foreign shareholders in a US corporation on the sale of their stock in that corporation. In the context of treaty override issues, the new version contains two interesting provisions. First, it specifically provides that existing treaty provisions which exempt such gains from US tax are not overridden (except where treaty-shopping is involved). This provision certainly reflects a positive development. Second, however, it contains a provision that in the case of gain resulting from a redemption or liquidation transaction which would be subject to the new tax but for a treaty, 'Such gain shall be treated as a dividend to the extent of the earnings and profits of the [US] corporation attributable to the stock.' Now anyone who can read this provision and immediately state 'This is not a treaty override' without having to suck in their cheeks to keep from laughing has much greater self-control than do I.

Such a recharacterization can currently take place under the US domestic rules that apply to all redemption transactions but the status of the shareholder as foreign or domestic is irrelevant. As disturbing as the drafting sleight-of-hand, however, is the justification offered in the 'Technical Description' that accompanied the Bill. There it is stated that the recharacterization provision is not a treaty override because some other countries treat liquidating distributions as dividends without violating a treaty capital gain exemption provision. It is true that some countries do treat liquidating distributions as dividends but, to the best of my knowledge, it is a rule of general application.

So while the Bill's general approach to treaty overrides is to be applauded, the attempt to disguise a treaty override as a recharacterization provision and the misuse of foreign law to justify it are disheartening. 
I offer a modest suggestion to US tax writers. Every tax bill should contain a section that if any provision in the bill is contrary to provisions in existing treaties, those treaties are terminated as of the day of enactment. The proposal has two advantages. First, it will stop self-righteous carping by those who think compliance with international law is important. Second, it will end the pratice of wounding our own international economic and political standing by shooting off one finger or toe at a time and replace it with a single bullet to the head. But then what would we editorialists have to write about? 